Bull. Chem. Soc. Ethiop. 2019, 33(3), 389-400.

ISSN 1011-3924

(c) 2019 Chemical Society of Ethiopia and The Authors

Printed in Ethiopia

DOI: https://dx.doi.org/10.4314/bcse.v33i3.1

\title{
GC/MS ANALYSIS OF THE ESSENTIAL OILS OF CUPRESSUS ARIZONICA GREENE, JUNIPERUS COMMUNIS L. AND MENTHA LONGIFOLIA L.
}

\author{
Farnaz Shafaie ${ }^{1 *}$, Shahram Aramideh ${ }^{1}$, Oruj Valizadegan ${ }^{1}$, Mohammad Hassan Safaralizadeh ${ }^{1}$, \\ and Nader Noroozi Pesyan ${ }^{2}$
}

${ }^{1}$ Department of Plant Protection, Faculty of Agriculture, Urmia University, Urmia, Iran

${ }^{2}$ Department of Organic Chemistry, Faculty of Chemistry, Urmia University, Urmia, Iran

(Received February 28, 2019; Revised July 28, 2019; Accepted August 11, 2019)

\begin{abstract}
The chemical composition of the essential oils obtained by hydrodistillation from Cupressus arizonica Greene, Juniperus communis L. and Mentha longifolia L. were determined by gas chromatography-mass spectrometry (GC/MS) analysis. The chemical composition of the essential oils were identified by GC/MS. Eicosane $(27.4 \%)$, umbellulone $(13 \%)$ and $\alpha$-pinene $(10.51 \%)$ were the major components of $C$. arizonica oil; sabinene $(32 \%)$, limonene $(26 \%)$ and bornyl acetate $(7.4 \%)$ were the major components of J. communis oil and pulegone (26\%), $L$-menthone (13.4\%) and cis-para-menthan-3,8-diol $(10.2 \%)$ were the major components of $M$. longifolia oil. The percentage of monoterpenes in the three essential oils was compared. The percentage of monoterpenes in C.arizonica is about $5.2 \%$, J. communis $46 \%$, and M. longifolia is $50.1 \%$. The percentage of terpenes in C. Arizonica (16.3\%), J. communis (5.2\%) and M. longifolia $(9.3 \%)$ were reported. But the percentage of cyclic monoterpenes in C. arizonica is about $6 \%$, J. communis $26.1 \%$, and M. longifolia is $3 \%$. Monoterpenes are the most components that make up essential oils.
\end{abstract}

KEY WORDS: Cupressus arizonica, Juniperus communis, Mentha longifolia, Essential oil, Chemical composition

\section{INTRODUCTION}

Essential oils have been of the supreme importance for fine pharmacology applications, aroma and cosmetic preparations for a long time, because of their intense, pleasant, sweet, and floral as well as their fixative properties [1-4]. In the last years the number of procedures using extraction of organic compounds from different matrices has increased. Result of analyses involves pretreatment method of the samples, extraction and condensation method to increase the analytic concentration to within gadget sensitivity. The extraction method, qualitative and quantitative analyses by using gas chromatography-mass spectrometric technique (GC/MS) are the steps followed for compounds identification $[5,6]$. The remedial possible of essential oils, like other plant-derived remedies, has yet to be fully realized. This is individually true of aromatic oils, which by their very nature have such a concentrated yet multifaceted approach make-up a small ratio of the world flora has been tested for pharmacologically active compounds, but with the ever-increasing danger of plants becoming extinguished, there is a real risk that many important plant sources may be los [7-9]. The exercise of aromatherapy could be seen as part of the larger field of herbal medicine, since the essential oil is only one of many ways in which a plant can be prepared as a treatment. Since all essential oils are derived directly from plants, it can be exquisite to see them within a botanical context rather than as isolated products. In some ways the use of aromatic oils for therapeutic purposes interests gas chromatography columns with different polarities have been designed for the analysis of compounds with a corresponding range of polarities. To comprehensively characterize the composition of an essential oil sample, chromatographic columns with different polarities should be accessible [10-13]. In this project, the chemical composition of three different oils of Cupressus arizonica Greene, Juniperus communis L. and Mentha longifolia L. was investigated and their compositional components identified. For example, some compounds such as eicosane

*Corresponding author. shafaiientomology@yahoo.com

This work is licensed under the Creative Commons Attribution 4.0 International License 
(27.4\%, in Table 1, raw 7 and column 2) were the main component in C. arizonica cultivated in North-West Iran while this compound is not the dominant component in other reports.

In other research reports, the most important components of essential oils from $M$. longifolia were menthol (33\%), menthone (21\%) and pulegone (18\%) [14]. Main identified compounds of the $C$. arizonica, $J$. communis and M. longifolia essential oil in several studies obtained by GC/MS showed that $\alpha$-pinene was the main components of the essential oil leaves of $C$. arizonica cultivated in Iran, Italy and Argentina [15,16]. $\alpha$-Pinene dominated in the most leaf oils of J. communis growing in Estonia [17], China [18] and Bulgaria [19]. The active components of essential oils are alkaloids, glycosides, steroids and volatile oils [20,21].

\section{EXPERIMENTAL}

\section{Plants material}

Aerial parts include leaves of Cupressus arizonica Greene (Cupressaceae), Juniperus communis L. (Cupressaceae) and Mentha longifolia L. (Lamiaceae) were collected from campus of Urmia University (West Azerbayjan Province, Urmia, Iran) in May 2017. These plants were dried in shadow (away from sunlight) and ventilated area at $32 \pm 2{ }^{\circ} \mathrm{C}$ for $2-10$ days. Each plant product was cut into small pieces using a blade and a chopping board then were kept in a refrigerator.

\section{Essential oil extraction}

Plant materials were milled into fine powder using a milling machine. $60 \mathrm{~g}$ of the plant samples to which $650 \mathrm{~mL}$ distilled water was added, were subjected to hydrodistillation using a modified Clevenger-type apparatus for 3 hours. Essential oils dried over anhydrous sodium sulfate and transferred into amber-colored vials at $4{ }^{\circ} \mathrm{C}$ for further tests [22].

\section{Sample preparation}

After the preparation of essential oils by hydrodistillation method, a quantity of $5 \mu \mathrm{L}$ from each of essential oil was mixed with $100 \mu \mathrm{L}$ hexane and a very small amount of sodium sulfate. Then $1 \mu \mathrm{L}$ from the new mixture was injected into the chromatograph.

\section{GC/MS analysis}

The analyses were performed in Jahad-e-Daneshgahi of Urmia, (West Azerbaijan Province, Urmia, Iran). The chemical composition of essential oils of $C$. arizonica, $J$. communis and $M$. longifolia were analyzed by GC/MS using a gas chromatography mass spectrometry system (Agilent 7890A/5975C GCMS System) equipped with HP-5 column $(30 \mathrm{~m} \times 0.1 \mathrm{~mm} ; 0.25 \mu \mathrm{m}$ film thickness). The oven temperature was held at $60{ }^{\circ} \mathrm{C}$ for $3 \mathrm{~min}$, programmed at $20{ }^{\circ} \mathrm{C} / \mathrm{min}$ to $240{ }^{\circ} \mathrm{C}$ and then held at this temperature for $8.5 \mathrm{~min}$. The carrier gas was helium $(99.99 \%)$ at a flow rate of $1 \mathrm{~mL} / \mathrm{min}$. Mass spectra were taken at $70 \mathrm{eV}$. The injector temperature was $280{ }^{\circ} \mathrm{C}$. Identification of the constituents of the oil was made by comparison of their mass spectra and retention indices (RI) with those given in the literature and those authentic samples [23]. Chemical compounds of essential oils include esters, aldehydes, alcohols, phenols, ketones and terpenes. Computer matching identified compounds used as references (Wiley and Mass Finder $3.1)[24,25]$. The comparative condensations of the separated compounds based on percentage were estimated based on chromatograms obtained from GC/FID/MS system. The chromatograms are shown in (Figures 1-3). 


\section{RESULTS AND DISCUSSION}

In this research extracted the herbal essential oils of $C$. arizonica, J. communis and M. longifolia using the GC/MS technique and identified the constituents of them. Results of the compounds of C. arizonica are considered in Table 1, the most constituents of the compounds are terpene, terpenoids and acyclic alkanes. The chemical composition of the essential oils of $C$. arizonica has 23 compounds. The major of them include eicosane $\left(\mathrm{C}_{20} \mathrm{H}_{42}\right):(27.4 \%)$, umbellulone $\left(\mathrm{C}_{10} \mathrm{H}_{14} \mathrm{O}\right)$ : $(13 \%)$ and $\alpha$-pinene $\left(\mathrm{C}_{10} \mathrm{H}_{16}\right)$ : $(11 \%)$ (Table 1$)$. The chemical composition of the essential oils obtained from $J$. communis have 25 compounds, the major of them include sabinene $\left(\mathrm{C}_{10} \mathrm{H}_{16}\right):(32 \%)$, limonene $\left(\mathrm{C}_{10} \mathrm{H}_{16}\right)$ : $(26 \%)$ and bornyl acetate $\left(\mathrm{C}_{12} \mathrm{H}_{20} \mathrm{O}_{2}\right):(7.4 \%)$ (Table 2). The chemical composition of the essential oils obtained from $M$. longifolia have 29 compounds, the major of them include pulegone $\left(\mathrm{C}_{10} \mathrm{H}_{16} \mathrm{O}\right)(26 \%), L$-menthone $\left(\mathrm{C}_{10} \mathrm{H}_{18} \mathrm{O}\right)$ : (13.4\%) and cis-p-menthan-3,8-diol $\left(\mathrm{C}_{10} \mathrm{H}_{20} \mathrm{O}_{2}\right):(10.2 \%)$ (Table 3$)$.

\section{Compositions of three essential oils}

The compositions of $C$. arizonica oil contain terpene (16.3\%), monoterpene (5.2\%), cyclic monoterpene $(6 \%)$, terpenoid $(1.4 \%)$, monoterpene ketone $(13 \%)$, terpineol $(5.4 \%)$, sesquiterpene alcohol (1.2\%), volatile terpene $(4.1 \%)$ and acyclic alkanes $(35.3 \%)$. Acyclic alkanes and sesquiterpene alcohols have the highest and the lowest percentage of compounds, respectively (Figure 4).

Table 1. Essential oil composition (\%w/w) of leaves of C. arizonica cultivated in North-West Iran.

\begin{tabular}{|l|l|l|l|l|l|l|l|}
\hline Component & RI & RT & Percentage & Component & RI & RT & Percentage \\
\hline$\alpha$-Pinene & 934 & 5.2 & 11 & Elemicin & 1560 & 19 & 1 \\
\hline Sabinene & 970 & 6 & 2 & Cedrol & 1608 & 20 & 1.2 \\
\hline$\beta$-Myrcene & 990 & 6.3 & 1 & 1 -Cubenol & 1635 & 20.3 & 4.1 \\
\hline O-Cymene & 1014 & 7.1 & 3 & $\alpha$-Acorenol & 1638 & 20.4 & 1 \\
\hline Limonene & 1030 & 7.2 & 6 & $\alpha$-Cadinol & 1657 & 21 & 1 \\
\hline Camphor & 1148 & 10 & 1.4 & Eudesm-7(11)-en-4-ol & 1694 & 21.4 & 4 \\
\hline Umbellulone & 1176 & 11 & 13 & Eicosane & 2158 & 29 & 27.4 \\
\hline Terpeinene-4-ol & 1179 & 11 & 4 & Tetratriacontane & 2390 & 31.2 & 1 \\
\hline$\alpha$-Terpineol & 1193 & 11 & 1.3 & Nonacosane & 2606 & 34 & 5 \\
\hline Alloaromadedrene & 1467 & 17 & 3.3 & Dotriacontane & 3046 & 40 & 1.4 \\
\hline 1s,cis-calamenene & 1525 & 18.2 & 3.4 & $17-$ Pentatriacontene & 3644 & 49 & 1 \\
\hline Candina-1(2),4-diene, cis & 1538 & 18.4 & 1 & & & & \\
\hline
\end{tabular}




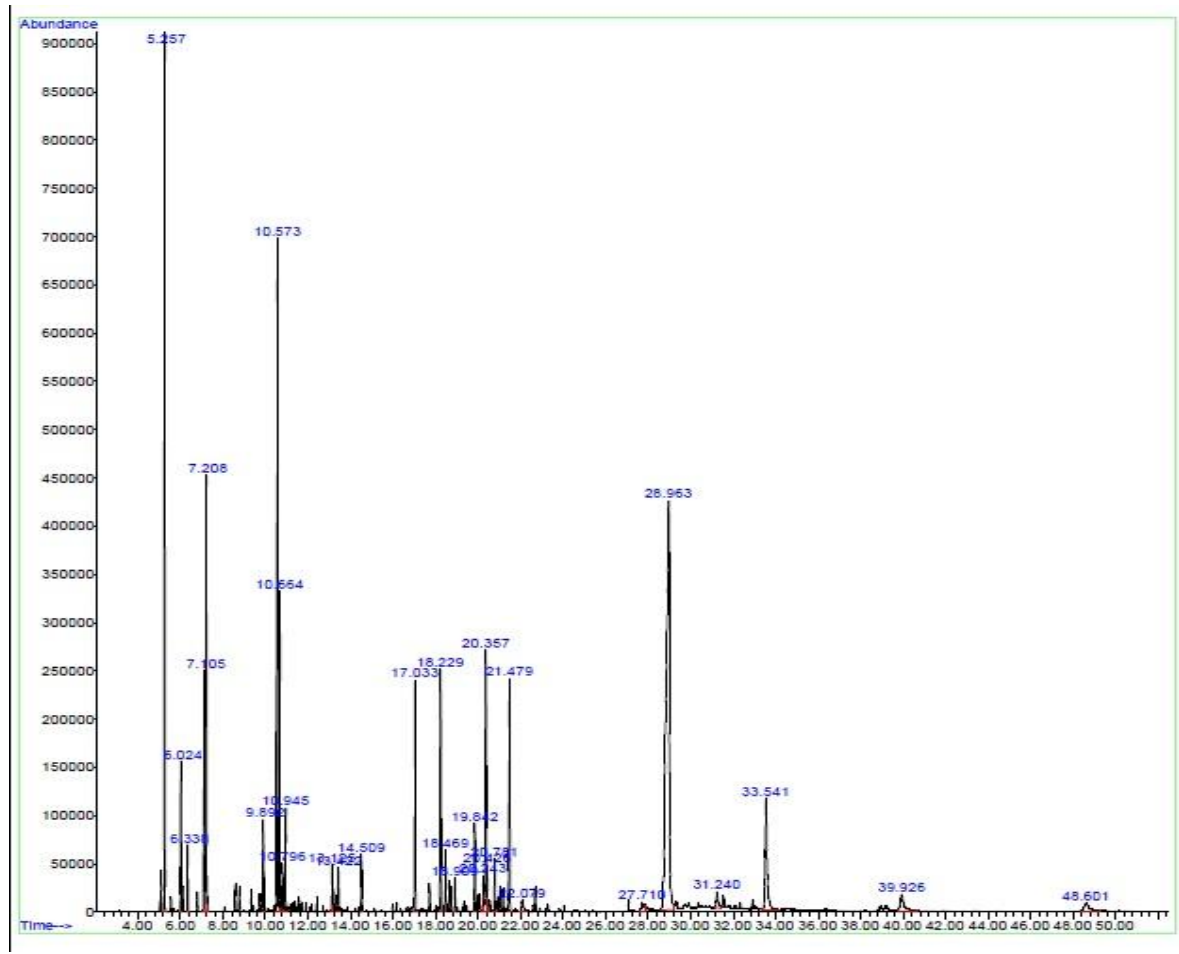

Figure 1. GC Chromatogram of C. arizonica leaves, run on a HP-5 capillary column.

Table 2. Essential oil composition (\%w/w) of leaves of J. communis cultivated in North-West Iran.

\begin{tabular}{|l|l|l|l|l|l|l|l|}
\hline Component & RI & RT & Percentage & Component & RI & RT & Percentage \\
\hline Thujene & 928 & 5.1 & 1 & Terpinene-4-ol & 1179 & 10.64 & 3.37 \\
\hline$\alpha$-Pinene & 934 & 5.2 & 1.2 & $\alpha$-Terpineol & 1193 & 12 & 1 \\
\hline Sabinene & 970 & 6 & 32 & Trans-carveol & 1219 & 12 & 0.3 \\
\hline$\beta$ - Myrcene & 989 & 6.3 & 3 & Isobronylformate & 1226 & 12 & 0.3 \\
\hline 1,4-Cineole & 1014 & 7 & 2 & Caryone & 1245 & 12.1 & 1 \\
\hline O-Cymene & 1014 & 7.1 & 3.3 & Bronyl acetate & 1287 & 13.1 & 7.4 \\
\hline Limonene & 1030 & 7.2 & 26 & Laranduly acetate & 1293 & 13.2 & 3.3 \\
\hline C-Terpinene & 1057 & 8 & 2 & A-Selinene,7-epi- & 1517 & 18 & 1 \\
\hline Linolool & 1098 & 9 & 2.1 & Germacrene B & 1551 & 19 & 3.4 \\
\hline $\begin{array}{l}\text { Limonene oxide, } \\
\text { trans- }\end{array}$ & 1122 & 10 & 1 & Cubenol,1,10-di-epi- & 1614 & 20 & 1 \\
\hline Terpen-1-ol & 1134 & 10 & 0.4 & A-Muurolol & 1645 & 21 & 1.2 \\
\hline camphor & 1148 & 10 & 1 & A-Cadinolii & 1658 & 21 & 2.3 \\
\hline $\begin{array}{l}\text { 3-Hexenyl } \\
\text { butanoate,(z)- }\end{array}$ & 1168 & 10.4 & 0.4 & & & & \\
\hline
\end{tabular}


GC/MS analysis of essential oils of C. arizonica greene, J. communis L. and M. longifolia L. 393

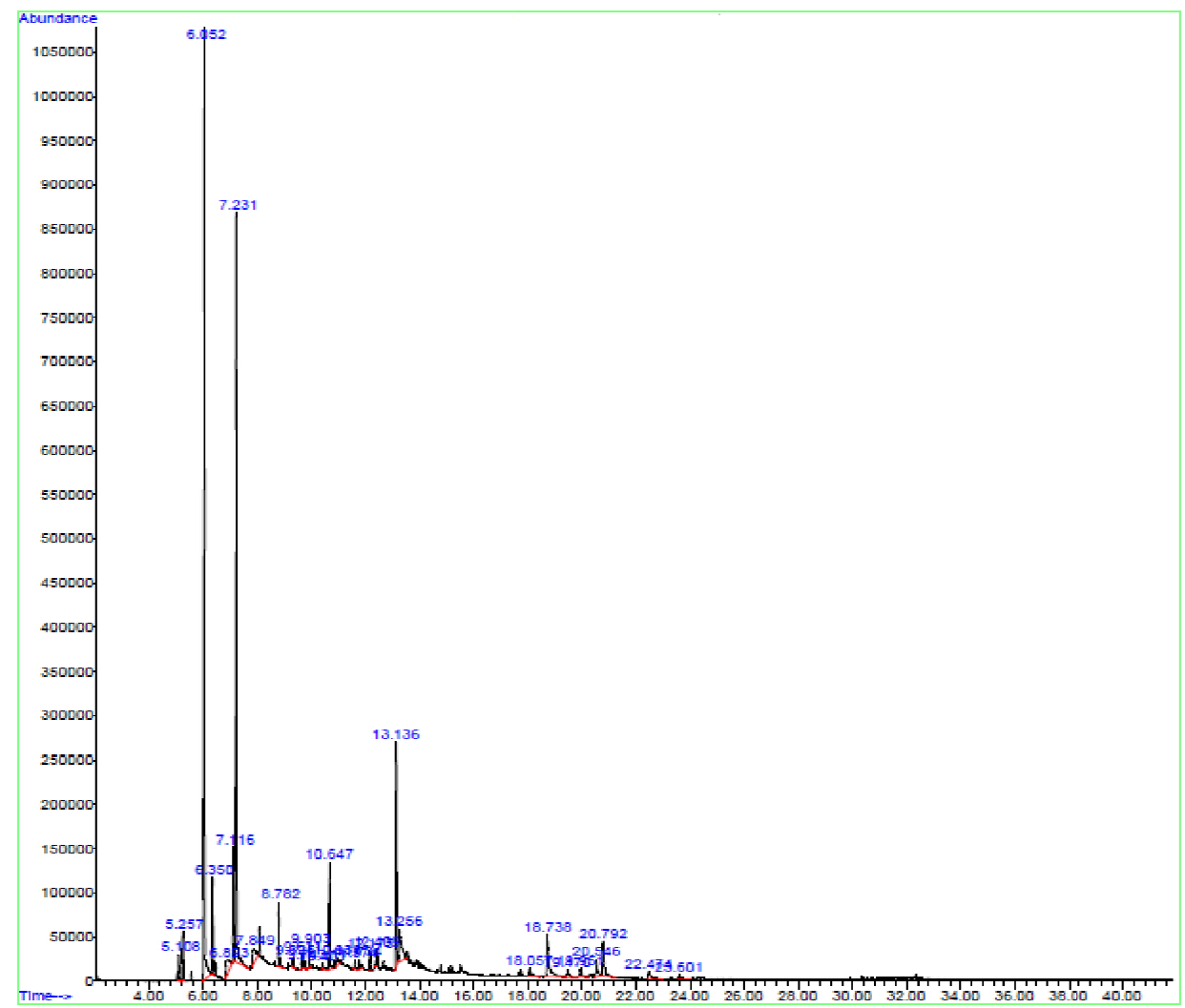

Figure 2. GCChromatogram of J. communisleaves, run on a HP-5 capillary column.

Table 3. Essential oil composition (\%w/w) of leaves of M. longifolia cultivated in North-West of Iran.

\begin{tabular}{|c|c|c|c|c|c|c|c|}
\hline Component & RI & RT & Percentage & Component & RI & RT & Percentage \\
\hline$\alpha$-Pinene & 934 & 5.2 & 5.4 & cis-Piperitone oxide & 1257 & 12.4 & 4 \\
\hline Sabinene & 970 & 6 & 1 & Thymol & 1280 & 13.1 & 1 \\
\hline$\beta$-myrcene & 990 & 6.3 & 1 & $p$-Cymen-7-ol & 1294 & 13.2 & 1 \\
\hline O-Cymene & 1014 & 7.1 & 1.1 & Piperitenone & 1343 & 14.3 & 1 \\
\hline Limonene & 1030 & 7.2 & 3 & $\alpha$-Terpinyl acetate & 1350 & 15 & 9.4 \\
\hline 1,8-Cineole & 1032 & 7.3 & 1 & Piperitenone oxide & 1368 & 15 & 2.1 \\
\hline Linalool $l$ & 1099 & 9 & 0.3 & trans-Caryophyllene & 1425 & 16.1 & 1 \\
\hline Camphor & 1148 & 10 & 1 & alloaromadendrene & 1467 & 17 & 1.3 \\
\hline l-Menthone & 1157 & 10.1 & 13.4 & 1s,cis-Calamene oxide & 1525 & 18.2 & 2.1 \\
\hline Isomenthone & 1166 & 10.3 & 2 & Caryophyllene oxide & 1589 & 19.4 & 1 \\
\hline $\begin{array}{l}\text { cis-p-Menthan- } \\
\text { 3,8-diol }\end{array}$ & 1175 & 11 & 10.2 & Cedrol & 1608 & 20 & 1 \\
\hline Terpinene-4-ol & 1179 & 11 & 3 & 1-Cubenol,epi- & 1635 & 30.3 & 2.4 \\
\hline$\alpha$-Terpinneol & 1193 & 11 & 1 & $\alpha$-Cadinol & 1657 & 21 & 1 \\
\hline $\begin{array}{l}\text { cis- } \\
\text { Dihydrocaryone }\end{array}$ & 1202 & 11.1 & 1 & Eudesm-7(11)-en-4-ol & 1694 & 21.4 & 3 \\
\hline Pulegone & 1240 & 12.1 & 26 & & & & \\
\hline
\end{tabular}

Bull. Chem. Soc. Ethiop. 2019, 33(3) 


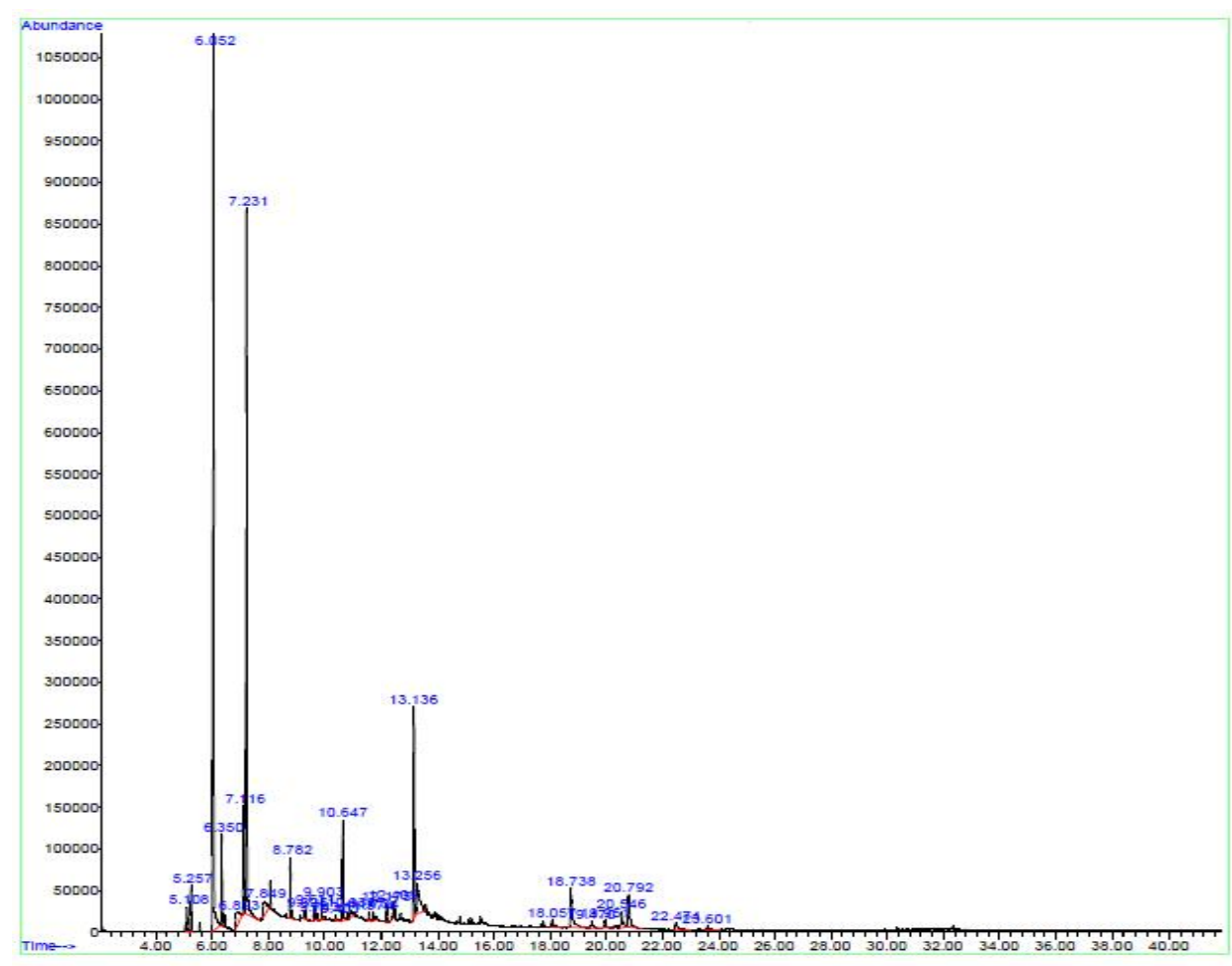

Figure 3. GC Chromatogram of M. Longifolia leaves, run on a HP-5 capillary column.

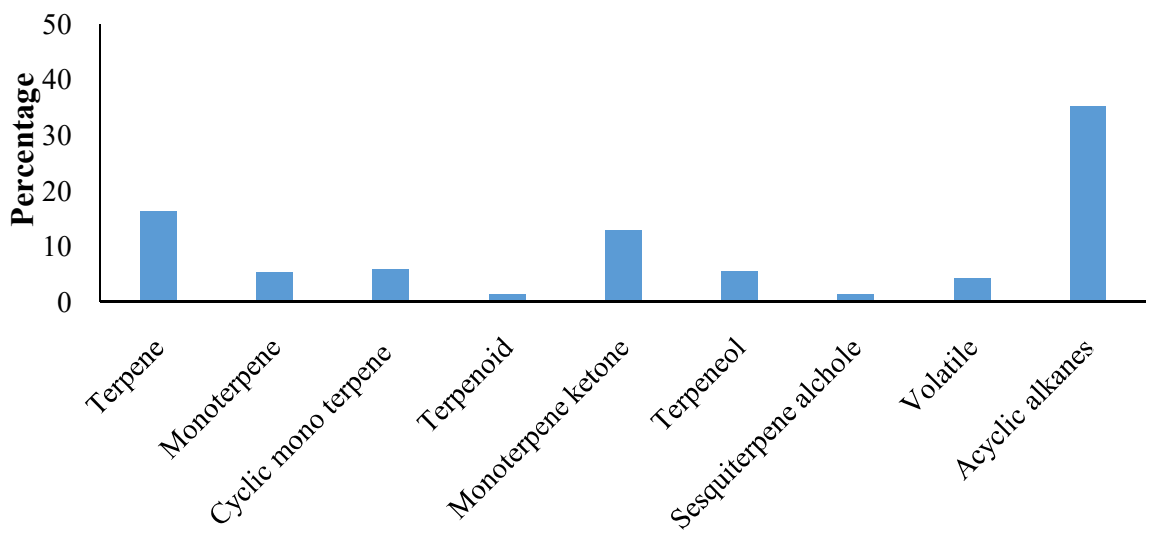

Components

Figure 4. The chart of effective percentage composition from leaves of C. Arizonica essential oil.

Bull. Chem. Soc. Ethiop. 2019, 33(3) 
GC/MS analysis of essential oils of C. arizonica greene, J. communis L. and M. longifolia L. 395

The compositions of $J$. Communis oil contain terpene (5.2\%), monoterpene (46\%), cyclic monoterpene (26.1), terpineol (4), terpinoid (1.2\%), monocyclic monoterpinoid alcohol $(0.3 \%)$, volatile organic hydrocarbons (4\%) and sesquiterpenoid alcohol (2.3\%). Monoterpenes and monocyclic monoterpinoid alcohol have the highest and the lowest percentage of compounds, respectively (Figure 5).

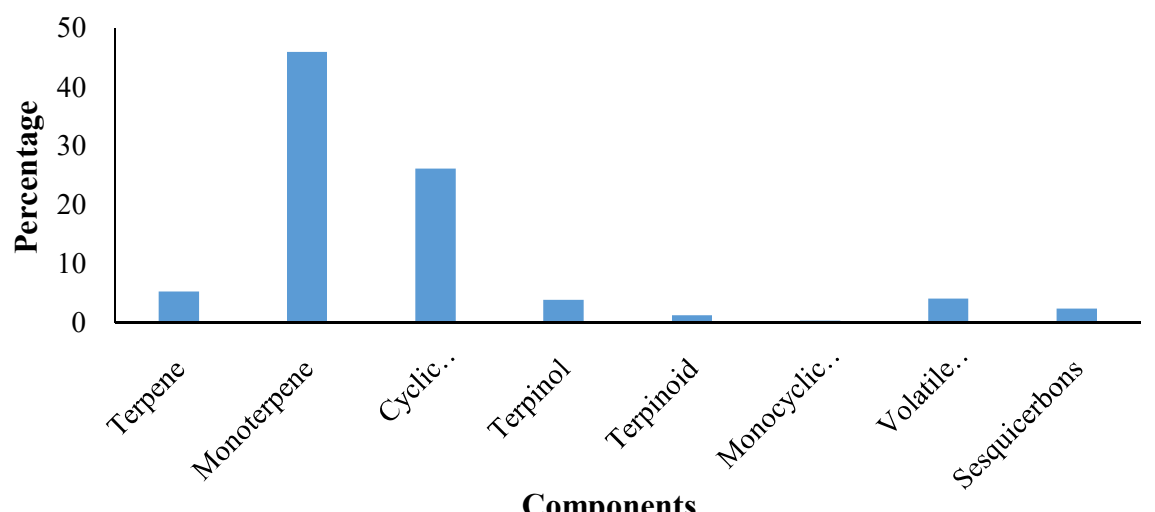

Figure 5. Effective percentage composition from leaves of J. communis essential oil.

The compositions of $M$. longifolia oil contain terpenes $9.3 \%$, monoterpenes $(50.1 \%)$, cyclic monoterpene (3\%), monoterpinoid (2\%), terpinoid (21.2\%), terpeneol (12.3\%), monoterpenol $(2.1 \%)$ and aromatic terpene (1\%). Monoterpenes and aromatic terpenes have the highest and the lowest percentage of compounds, respectively (Figure 6). Representatively, molecular structures of some terpenes are shown in Figure 7.

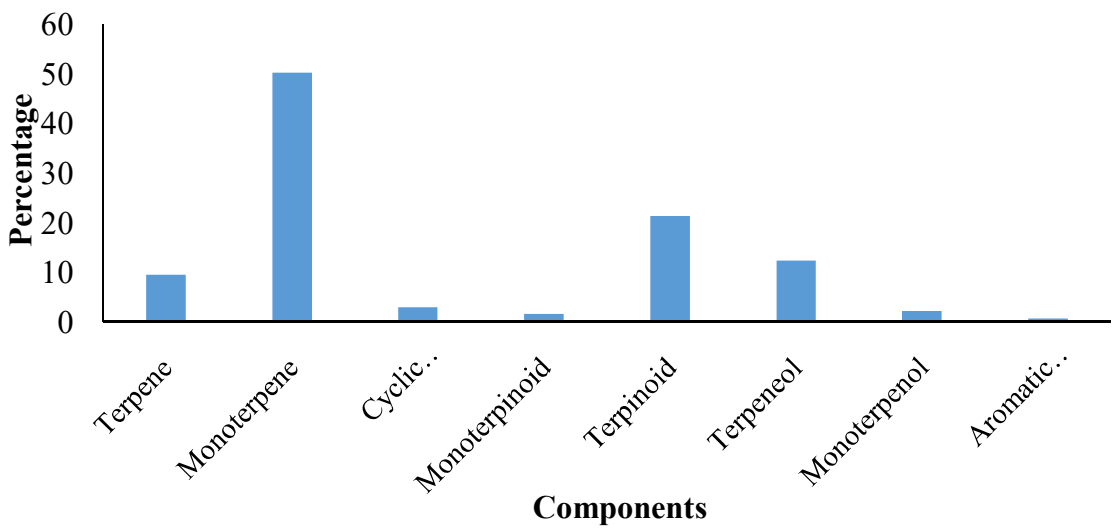

Figure 6. Effective percentage composition from leaves of M. longifolia essential oil. 


\section{Examples of monoterpene}<smiles>CC1=CCC2CC1C2(C)C</smiles>
alpha-pinene beta-pinene<smiles>C=C1CCC2CC1C2(C)C(=O)O</smiles><smiles>C=C1CC[C@@]2(C(C)C)C[C@H]12</smiles>

sabinene<smiles>C=C(C)[C@H]1CC=C(C)CC1</smiles>

limonene<smiles>CC(C)[C@H]1CC[C@@H](C)C[C@H]1O</smiles>

menthol

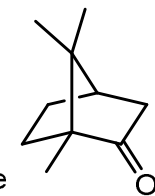

camphor

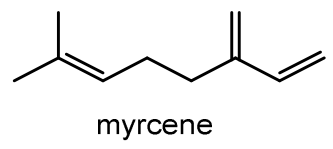

myrcene

\section{Sesquiterpene}

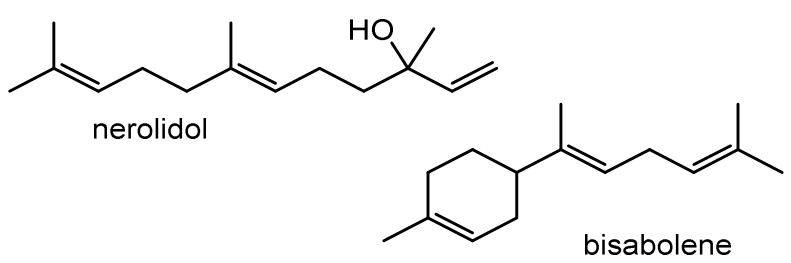

Diterpene

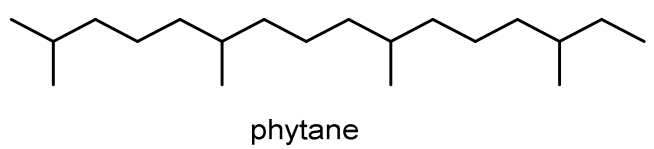

Figure 7. Molecular structures of some terpenes.

GC/MS is a structural analysis tool which plays a key role in medical, pharmacy, agriculture, the analysis of essential oils, pesticides and other classes of compounds. The results of the analysis of three essential oils by gas chromatography in this survey with other researchers from different places show that there are differences between the percentages of the ingredients. The chemical constituents of $M$. longifolia oil collected by [26] from Tehran province in Iran (located in central Iran), extracted by the same conditions as described in this study were comprised of carvone (62\%) and limonene (19.4\%) as the major constituents with 23 compounds. According to [27] reports from Taif in Saudi Arabia, with 38 compounds, pulegone $(33.2 \%)$, and menthone (29\%) were comprised the major constituents. The essential oil composition of $M$. longifolia, cis-epoxy piperitone (18.4\%), pulegone $(15.5 \%)$ and piperitenone oxide (15\%) were as main components in Turkey [28]. The other research by [29] from five regions in South-West of Iran the major compounds were piperitenone oxide $(7.4-60 \%)$, 
pulegone (4-49.4\%). The present research was conducted in North-West of Iran with 29 compounds, pulegone $(26 \%)$ and $L$-menthone $(13.4 \%)$ were the major constituents. The essential oil from $M$. longifolia species including secondary metabolite components such as menthol, menthone and limonene studied for their insecticidal activity against several stored product pests $[30,31]$.

Angioni et al. [32] reported that the essential oils from leaves of $J$. communis from Italy with 35 components, sabinene with $61 \%$ was dominated. Also, according to Shahmir et al. [33] reported that sabinene was the dominat compound in Northern Iran $(19.2 \%)$ and the effective compositions of $J$. communis included monoterpene (83.2\%) and sesquiterpene (1.2\%). Results of this present study from North-West of Iran showed that the essential oil composition of $J$. communis with 25 components, sabinene (32\%), limonene $(32 \%)$ and bronyl acetate $(7.4 \%)$ were as main components and the effective compositions included monoterpene calculated (46\%). The present results showed that sabinene was the dominate component with difference in percentage, therefore is in agreement with sample from Italy and Iran [32, 33]. Carroll et al. [18] reported the major component of the essential oils from leaves of $J$. communis oil from China was $\alpha$-pinene (27\%). Sela et al. [34] reported that the chemical composition of fifteen samples of juniper essential oil locations in Republic of Macedonia showed that the major components were $\alpha$-pinene $(16-43.1 \%), \beta$-pinene $(2 \%-5.3 \%), \beta$-myrcene $(3 \%-26.5 \%)$ and sabinene (3$12 \%)$. Buci et al. [35] reported the chemical composition of the essential oils of J. communis from Albania there were 56 compounds and the principal were: $\alpha$-pinene $(36 \%)$, $\beta$-myrcene (45 $\%$ ), sabinene (10\%) and germacene D (5\%). Also, the effective composition of J. communis oils was monoterpene (72\%). The composition of the essential oil from the leaves of $J$. communis in present research is different from that of the essential oil of China, Republic of Macedonia and Albania, but in the other studies $\alpha$-pinene was dominate.

Cheraif et al. [36] reported that the essential oil from leaves of C. arizonica from Tunisia was dominated $\alpha$-pinene $(20 \%)$, umbellulone $(18.4 \%)$ and limonene $(5.8 \%)$. Analysis of volatile compounds from $C$. arizonica leaves has been the subject of several investigations in six other countries. These previous studies showed that $\alpha$-pinene was the main components of the oil obtained from the leaves of $C$. arizonica cultivated in Isfahan (located in central region), Iran (19.2\%) [15], Argentina (23\%) [16], Italy (8\%) [37]. Our result showed that the eicosane with $(27.4 \%)$ was the main components of this essential oil from Iran. The result of this research is different from the results of other researchers.

There are differences among the major compounds, the number of compounds and the percentage of the essential oils in our study compared to other similar reports. Comparing the results obtained from GC/MS analysis, herbal essential oils showed remarkable difference from the same species cultivated in other countries. These differences can be related to several factors like the geographic and climate conditions, plant organs used and methods for extraction of essential oils, season of sampling and soil composition [38-40]. Characterization of the compounds by comparison of mass spectra and retention indices with literature records showed that C. arizonica, J. communis and M. longifolia are composed mainly of monoterpene $(18.1,46$ and $50.1 \%)$ and cyclic monoterpene $(6,26.1$ and $3 \%)$, respectively.

\section{CONCLUSION}

In summary, in this study, the GC-MS analysis of the percentage chemical composition of essential oils extracted from leaves of $C$. arzonica, J.communis and M. longifoliain North-West Iran including the major components of three essential oils eicosane $(27.4 \%)$, sabinene $(32 \%)$ and pulegone $(26 \%)$, respectively. Also, the eicosane, sabinene and pulegone were dominant components of C. arzonica, J.communis and M. longifolia oils, respectively. In literature there are differences among the major compounds and the number and percentages of compounds in essential oils of plants. These differences can be due to factors such as geographic location, 
plant organs used, extraction methods, season of sampling and soil composition. Therefore, all these factors affected the results of present study.

\section{ACKNOWLEDGMENTS}

We are grateful to the research council of Urmia University and Jahad e Daneshgahi of Urmia for support of the present survey.

\section{REFERENCES}

1. Roberto, D.; Micucci, P.; Sebastian, T.; Graciela, F.; Anesini, C. Antioxidant activity of limonene on normal murine lymphocytes: Relation to $\mathrm{H}_{2} \mathrm{O}_{2}$ modulation and cell proliferation. Basic Clin. Pharmacol. Toxicol. 2010, 106, 38-44.

2. Karioti, A.; Hadjipavlou-Litina, D.; Mensah, M.L.K.; Fleischer, T.C.; Skaltsa, H. Composition and antioxidant activity of the essential oils of Xylopia aethiopica (Dun) A. Rich. (Annonaceae) leaves, stem bark, root bark, and fresh and dried fruits, growing in Ghana. J. Agric. Food Chem. 2004, 52, 8094-8098.

3. Sharifi-Rad, M.; Ozcelik, B.; Altın, G.; Daşkaya-Dikmen. C.; Martorell, M.; RamírezAlarcón, K.; Alarcón-Zapata, P.; Morais-Braga, M.F.B.; Carneiro, J.N.P.; Leal, A.L.A.B.; Coutinho, H.D.M.; Gyawali, R.; Tahergorabi, R.; Ibrahim, S.A.; Sahrifi-Rad, R.; Sharopov, F.; Salehi, B.; Contreras, M.M.; Sharifi-Rad, J. Salvia spp. plants-from farm to food applications and phytopharmacotherapy. Trends Food Sci. Technol. 2018, 80, 242-263.

4. Mishra, A.P.; Saklani, S.; Salehi, B.; Parcha, V.; Sharifi-Rad, M.; Milella, L.; Iriti, M.; Sharifi-Rad, J.; Srivastava, M. Satyrium nepalense, a high altitude medicinal orchid of Indian Himalayan region: chemical profile and biological activities of tuber extracts. Cell. Mol. Biol. 2018, 64, 35-43.

5. Manfredini, V.; Roehrs, R.; Peralba, M.C.R.; Henriques, J.A.P.; Saffi, J.; Ramos, A.L.L.P.; Benfato, M.S. Glutathione peroxidase induction protects Saccharomyces cerevisiae Sod1deltasod2delta double mutants against oxidative damage. Braz. J. Med. Biol. Res. 2004, 37, 159-165.

6. Mensor, L.L.; Menezes, F.S.; Leitao, G.G.; Reis, A.S.; Dos Santos, T.C.; Coube, C.S.; Leitão, S.G. Screening of Brazilian plant extracts for antioxidant activity by the use of DPPH free radical method. Phytother. Res. 2001, 15, 127-130.

7. Hoferl, M.; Stoilova, I.; Schmidt, E.; Wanner, J.; Jirovetz, L.; Trifonova, D.; Krastev, L.; Krastanov, A. Chemical composition and antioxidant properties of juniper berry (Juniperus communis L.) essential oil. Action of the essential oil on antioxidant protection of Saccharomyces cerevisiae model organism. Antioxidants 2014, 3, 81-98.

8. Stoilova, I.S.; Wanner, J.; Jirovetz, L.; Trsfonova, D.; Krasterv, L.; Stoyanova, A.; Krastanov, A.I. Chemical composition and antioxidant properties of Juniper berry (JVNICL.) essential oil. Bulg. J. Agric. Sci. 2014, 20, 227-237.

9. Ramak, P.; Kazempour Osaloo, Sh.; Sharifi, M.; Ebrahimzadeh, H.; Behmanesh, M. Biosynthesis, regulation and properties of plant monoterpenoids. Academic J. 2014, 8, 983991.

10. Pepeljnjak, S.; Kosalec, I.; Kalodera, Z.; Blazevic, N. Antimicrobial activity of Juniper berry essential oil (Juniperus communis L., Cupressaceae). Acta Pharm. 2005, 55, 417-422.

11. Sela, F.; Karapandzova, M.; Stefkov, G.; Cvetkovikj, I.; Trajkovska-Dokik, E.; Kaftandzieva, A.; Kulevanova, S. Chemical composition and antimicrobial activity of leaves essential oil of Juniperus communis (Cupressaceae) grown in Republic of Macedonia. Macedonian Pharm. Bull. 2013, 59, 23-32. 
12. Traboulsi, A.F.; El-Haj, S.; Tueni, M.; Taoubi, K.; N.A. Nader, N.A.; Mrad., A. Repellency and toxicity of aromatic plant extracts against the mosquito Culex pipiensmolestus (Diptera: Culicidae). Pest Manag. Sci. 2005, 61, 597-604.

13. Milos, M.; Radonic, A. Gas chromatography mass spectra analysis of free and glycosidically bound volatile compounds from Juniperus oxycedrus L. growing in Croatia. Food Chem. 2000, 68, 33-338.

14. Hafedh, H.; Fethi, B.A.; Mejdi, S.; Emira, N.; Amina, B. Effect of Mentha longifolia L. essential oil on the morphology of four pathogenic bacteria visualized by atomic force microscopy. Afr. J. Microbiol. Res. 2010, 4, 1122-1127.

15. Afsharypuor, S.; Tavakoli, P. Essential oil constitnents of leaves and fruits of Cupressus arizonica Greene. J. Essent. Oil Res. 2005, 17, 225-226.

16. Malizia, R.A.; Acardell, D.; Molli, J.S.; Gonzalez, S.; Guerra, P.E.; Grau, R.J. Volatile constituents of leaf oils from Cupressaceae family part I. Cupressus torulosa Dos species growing in Argentina. J. Essent. Oil Res. 2000, 12, 59-63.

17. Orav, A.; Kailas, T.; Murrisepp, M. Chemical investigation of the essential oil from berries and needles of common juniper (Juniperus communis L.) growing wild in Estonia. Nat. Prod. Res. 2010, 24, 1789-1799.

18. Carroll, J.F.; Tabanca, N.; Kramer, M.; Elejalde, N.M.; Wedge, D.E.; Bernier, U.R.; Coy, M.; Becnel, J.J.; Demirci, B.; Baser, K.H.C.; Zhang, J.; Zhang, S. Essential oils of Cupressus funebris, Juniperus communis and Juniperus chinensis (Cupressacea) as repellents against ticks (Acari: Ixodidae) and as toxicants against mosquitoes. J. Vector Ecol. 2011, 36, 258-268.

19. Adams, R.P.; Tashev, A.N. The volatile leaf oils of Juniperus communis varieties from Bulgaria. Phytol. 2013, 95, 302-307.

20. Park, I.K.; Lee, S.G.; Choi, D.H.; Park, J.D., Ahn, Y.J. Insecticidal activities of constituents identified in the essential oil from leaves of Chamaecyparis obtusa against Callosobruchus chinensis (L.) and Sitophilus oryzae (L.). J. Stored Prod. Res. 2003, 39, 375-378.

21. Lee, B.H.; Lee, S.E.; Annis, P.C.; Pratt, S.J.; Park, B.S.; Tumaalii, F. Fumigant toxicity of essential oils and monoterpenes against the red flour beetle, Tribolium castaneum Herbst. $J$. ASIA-PAC Entomol. 2002, 5, 237-240.

22. Negahban, M.; Moharramipour, S.; Sefidkon, F. Fumigant toxicity of essential oil from Artemisia sieberi Besser against three stored-product insects. J Stored Prod Res. 2007, 43, 123-128.

23. Adams, R.P. Quadruple Mass Spectra of Compounds Listed in Order of Their Retention Time on DB-5. Identification of Essential Oils Components by Gas Chromatography/Quadrupole Mass Spectroscopy, Allured Publishing Co: Carol Stream IL, USA; 2001; p 456.

24. Koenig, W.A.; Joulain, D.; Hochmuth, D.H. Terpenoids and related constituents of essential oils. Mass Finder 3 in Convenient and Rapid Analysis of GC/MS, Hochmuth, D.H. (Ed.), Hochmuth Scientific Consulting: Hamburg, Germany; 2004; 493.

25. Mc Lafferty, F.W.; Stauffer, D.B. The Wiley/NBS registry of mass spectral data. J. Chem. Educ. 1989, 66, 1-7.

26. Monfared, A.; Nabid, M.R.; Rustaeiyan, A.A.H. Composition of a carvone chemotype of Mentha longifolia L. Huds from Iran. J. Essent. Oil Res. 2002, 14, 51-55.

27. Salman, M.; Abdel Hamed, E.S.S.; Bazaid, A.S.; Dabi, M.M. Chemical composition for hydro distillation essential oil of Mentha longifolia by gas chromatography-mass spectrometry from North regions Kingdom of Saudi Arabia. Der Pharma Chimica. 2015, 7, 34-40.

28. Gulluce, M.; Sahin, F.; Sokmen, M.; Ozer, H.; Daferera, D.; Sokmen, A.; Polissiou, M.; Adiguzel, A.; Ozkan, H. Antimicrobial and antioxidant properties of the essential oils and 
methanol extract from Mentha longifolia L. ssp. longifolia. Food Chem. 2007, 103, 14491456.

29. Saeidi, Z.; Babaahmadi, H.; Saeidi, K.A.; Salehi, A.; Saleh Jouneghani, S.; Amirshekari, H.; Taghipour, A. Essential oil content and composition of Mentha longifolia (L.) Hudson grown wild in Iran. J. Med. Plants Res. 2011, 6, 4522-4525.

30. Michaelraj, S.; Sharma, K.; Sharma, R. Fumigant toxicity of essential oils against key pests of stored maize. Plant Protect. Sci. 2008, 16, 356-359.

31. Kumar, P.; Mishra, S.; Malik, A.; Satya, S. Insecticidal properties of Mentha species: A review. Ind. Crops Prod. 2011, 34, 802-812.

32. Angioni, A.; Barras, A.; Russo, M.T.; Coroneo, V.; Dessi, S.; Cabras, P. Chemical composition of the essential oils of Juniperus from ripe and unripe berries and leaves and their antimicrobial activity. J. Agric. Food Chem. 2003, 51, 3073-3078.

33. Shahmir, F.; Ahmadi, L.; Mirza, M.; Korori, S.A.A. Secretory elements of needles berries of Juniperus communis L. ssp. Communis and volatile constituents. Flavour Frag. J. 2003, 18, 425-428.

34. Sela, F.; Karapandzova, M.; Stefkov, G.; Kulevanova, S. Chemical composition of berry essential oils from Juniperus communis L. (Cupressaceae) growing wild in Republic of Macedonia and assessment of the chemical composition in accordance to European Pharmacopoeia. Maced. Pharm. Bull. 2011, 57, 43-51.

35. Buci, A.; Hodaj Celiku, E.; Manaj, H.; Abazi, S.; Drushku, S.; Lazari, D. Essential oil composition from Juniperus communis originated from Albania. Int. J. Environ. Appl. Sci. 2018, 13, 15-19.

36. Cheraif, H.; Jannet, B.; Hammami, M.; Khouja, M.L.; Mighri, Z. Chemical composition and antimicrobial activity of essential oils of Cupressus arizonica Greene. Biochem. Syst. Ecol. 2007, 35, 813-820.

37. Flamini, G.; Cioni, P.L.; Morelli, I.; Bighilli, A.; Castola, V.; Casanora, J. GC/MS and ${ }^{13} \mathrm{C}$ NMR integrated analyses of the essential oils from leaves, branches and female cones of Cupressus arizonica from Italy. J. Essent. Oil Res. 2003, 15, 302-304.

38. Bakkali, F.; Averbeck, S.; Averbeck, D.; Idaomar, M. Biological effects of essential oils a review. Food Chem. Toxicol. 2008, 46, 446-475.

39. Jaymand, K.; Rezaie, M.B. Chemical Compounds in Medicinal Plants, Publication of Research Institute of Forests and Rangelands of Iran: Iran; 2001; p 180.

40. Farooqi, A.; Sharama, S.; Naqvi, A.; Khan, A. Effect of kinetin of flower and oil production in Rosa domscena. J. Essent. Oil Res. 1993, 5, 305-309. 